42 Breathnach SM, Carrington P, Black MM. Neutrophil leukocyte migration in psoriasis vulgaris. I Invest Dermatol 1981;76:271-4.

43 Lazarus GS, Yost FJ, Thomas CA. Polymorphonuclear leukocytes: possible mechanism of accumulation in psoriasis. Science 1977;198:1162-3.

44 Dubertret L, Bertaux B, Fosse M, Touraine R. Psoriasis: a defect in the regulation of epidermal proteases, as shown by serial biopsies after cantharidin application. Br $\mathcal{J}$ Dermatol 1984;110: 405-10.

45 Baker BS, Swain AF, Valdimarsson H, Fry L. T-cell subpopulations in the blood and the skin of patients with psoriasis. BrF Dermatol 1984;110:37-44.

46 Guilhou JJ, Clot J. Cellular immunity in psoriasis. Acta Derm Venereol (Stockh) 1984;(suppl 113):25-8.

47 Geerdink JPM. Immunology. In: Mier PD, van de Kerkhof PCM, eds. Textbook of psoriasis. Edinburgh: Churchill Livingstone, 1986:150-64.

48 Baker BS, Griffiths CEM, Lambert S, et al. The effects of cyclosporin A on T lymphocyte and dendritic cell subpopulations in psoriasis. Br $\mathcal{J}$ Dermatol 1987;116:503-10.

\section{What every doctor needs to know about 11 November}

From 11 November, with only a few exceptions, patients will have the right to see computer records that doctors or others may hold on them. The Data Protection Act, which has been introduced in stages, will become fully operational on that day, and the Data Protection Registrar will have powers to enforce compliance. "Data subjects" (patients) will have the right, after making a written request and paying a fee of not more than $£ 10$, to be told by the registered "data user" (a doctor, practice, or health authority with computer records) whether any personal information about them is held on computer files; they then have the right to be supplied with a copy of that information within $\mathbf{4 0}$ days. Before 11 November Parliament is to be asked to approve an order that will enable doctors to prevent access being given to information they consider "likely to cause serious harm" to the physical or mental health of the patient or another person.

What are the implications for doctors? Firstly, they will need to think more carefully about what is entered into computer files. Secondly, those who recorded personal health data on disc or tape before the idea of patients having a right to see their records was contemplated should consider reviewing and editing such records before 11 November. No such action is necessary with records held solely for research as these are exempt from access rights; and information held solely for word processing falls outside the act. Thirdly, doctors identified as having overall clinical responsibility for the patient who is seeking access to records will be asked by whoever is acting as data protection coordinator to scrutinise within a week or so the applicant's computer record and manual case notes to decide whether any data in the computer record need to be withheld or made more understandable. These doctors will usually need to consult with the other people who have contributed substantially to the patient's record. On the rare occasions when modified access is considered essential the doctor must indicate exactly what part of the computer record should be withheld and why. He should also decide whether the patient should be counselled about the record when it is made available.

How much extra work this will mean is not known. There may well be an initial surge of requests stimulated by the media and the freedom of information lobby. Subsequently requests may correlate with litigation and the numbers of patients under psychiatric care. Distrust of computers may lead some patients to request access, but generally such requests should be viewed as reflecting a breakdown in the mutual trust that should exist between patient and doctor.
Time spent fostering this relationship may reduce the time spent in dealing with requests to see records.

Those who want to know more should consult the excellent booklets explaining the legislation in practical terms that are available free from the Office of the Data Protection Registrar ${ }^{1-8}$; and specific guidance on how requests for access to personal health data should be handled has recently been issued by the Department of Health and Social Security.9 At least those who are to function as data protection coordinators should now be familiar with these documents.

In the future the illogicality of treating computer held medical records differently from manual records will undoubtedly lead to pleas for patients to be granted rights of access to their whole medical record. Such a policy of openness was recommended by the Steering Group on Health Services Information, ${ }^{10}$ but the practical difficulties of implementing it are formidable.

Professor of Chemical Pathology,

FREDERICK V FLYNN

University College Hospital,

London WCIE 6AU

\footnotetext{
1 Data Protection Registrar. Data Protection Act 1984. Grideline I: introduction to the Act. Wilmslow, Cheshire: Office of the Data Protection Registrar, 1987.

2 Data Protection Registrar. Data Protection Act 1984. Grideline 2: the definitions. Wilmslow, Cheshire: Office of the Data Protection Registrar, 1987.

3 Data Protection Registrar. Data Protection Act 1984. Guideline 3: the registrar and registration. Wilmslow, Cheshire: Office of the Data Protection Registrar, 1987.

4 Data Protection Registrar. Data Protection Act 1984. Grideline 4: the data protection principles. Wilmslow, Cheshire: Office of the Data Protection Registrar, 1987.

Data Protection Registrar. Data Protection Act 1984. Grideline 5: individual's rights. Wilmslow, Cheshire: Office of the Data Protection Registrar, 1987.

Data Protection Registrar. Data Protection Act 1984. Guideline 6: the exemptions. Wilmslow, Cheshire: Office of the Data Protection Registrar, 1987.

Data Protection Registrar. Data Protection Act 1984. Guideline 7: enforcement and appeals. Wilmslow, Cheshire: Office of the Data Protection Registrar, 1987.

Data Protection Registrar. Data Protection Act 1984. Guideline 8: summary for computer bureaur. Wilmslow, Cheshire: Office of the Data Protection Registrar, 1987.

9 Department of Health and Social Security. Data Protection Act 1984: modified access to personal health information. London: Department of Health and Social Security, 1987. (HC(87)14.)

10 Steering Group on Health Services Information. A report from the confidentiality working group. London: Department of Health and Social Security, 1984.
}

\section{Should bronchodilators be combined in chronic bronchitis and emphysema?}

There is a new enthusiasm for combining oral theophyllines with inhaled $\beta_{2}$ agonists to achieve better bronchodilatation in patients with chronic obstructive airways disease. Ipratropium bromide and high dose topical steroids may even be added. We need to consider carefully the value of this moderately expensive polypharmacy.

Theophylline has been used for many years, but how it achieves bronchodilatation remains unclear. Earlier notions of phosphodiesterase inhibition appear unlikely,,$^{12}$ at least at therapeutic plasma concentrations of $10-20 \mathrm{mg} / \mathrm{l}$, and so do intracellular calcium translocation ${ }^{3}$ or antagonism of either adenosine receptor receptors ${ }^{4}$ or prostaglandins. ${ }^{5}$ In patients with asthma oral theophylline may potentiate the bronchodilatation from an inhaled $\beta_{2}$ agonist without increasing muscle tremor. ${ }^{6}$ A similar useful interaction has now been shown in patients with chronic bronchitis who show some bronchodilatation from salbutamol alone. ${ }^{7}$ In some (but not all) such patients bronchodilatation may be increased by adding ipratropium bromide to an inhaled $\beta_{2}$ agonist. ${ }^{8}$ This 
leads to the proposal that combining a slow release oral theophylline with both an inhaled $\beta_{2}$ agonist and ipratropium may achieve better bronchodilatation. ${ }^{910}$ Many patients fail to use a metered dose inhaled properly, despite repeated instruction, so that inhalation through a reservoir devicefor example, Nebuhaler, Ventamatic - which ensures most efficient delivery of the inhaled drugs to the lungs, ${ }^{11}$ also seems sensible. Adding a high dose topical steroid by a reservoir inhaler may yield further bronchodilatation ${ }^{12}$ and spare the need for oral steroids - as in patients with asthma. ${ }^{13}$ In patients with severe airflow obstruction $15-7.5 \mathrm{mg} /$ day of oral prednisolone appeared to prolong survival over 14-18 years of follow up. ${ }^{14}$ Can a similar benefit be obtained by inhaled steroids, with less risk of side effects? Clearly this polypharmacy (which has not yet been proved by controlled trial) can be justified only if bronchodilatation is shown objectively, as by a rise in peak expiratory flow rate measured four times daily over several weeks. ${ }^{12}$

Much attention has recently focused on respiratory muscle function in patients with chronic airflow obstruction, and it has been proposed that theophylline may improve diaphragmatic contractility and delay the onset of diaphragmatic fatigue. ${ }^{15}$ Animal ${ }^{16}$ and some human studies ${ }^{15}$ report improvements in transdiaphragmatic pressure generation at therapeutic concentrations of theophylline, but other studies do not. ${ }^{17}$ Any such effects are, however, less obvious in patients with chronic bronchitis and emphysema: thus in 15 such patients 30 days of theophylline increased maximal transdiaphragmatic pressure and reduced diaphragmatic fatigue, and the mean forced expiratory volume in one second $\left(\mathrm{FEV}_{1}\right)$ also rose from 0.6 to $0.81 .{ }^{18}$ In contrast, in 14 similar patients maximal inspiratory pressures were not changed by theophylline, and the six minute walking distance increased on average by only $6 \%$, but the $\mathrm{FEV}_{1}$ again rose from 0.8 to $0.91 .^{19}$ The respiratory muscles are most stressed in exercise, yet most double blind studies using objective assessment of exercise tolerance show no (or only minor) improvement from theophylline in patients with chronic bronchitis and emphysema. ${ }^{20-24}$

Thus an oral theophylline combined with an inhaled $\beta_{2}$ agonist can yield useful bronchodilatation in patients with chronic bronchitis and emphysema, but any improvement in respiratory muscle function ${ }^{25}$ in such patients is probably only a fringe benefit-and like other such benefits even this may be taxed. Oral theophylline passes into lung lining fluids and can then halve the bactericidal activity of alveolar macrophages. ${ }^{26}$ As acute exacerbations of respiratory failure most often arise from infection in these patients, ${ }^{27}$ using theophylline to improve respiratory muscle function in such exacerbations may be unwise.

\section{C FLENLEY}

Professor of Respiratory Medicine,

University of Edinburgh,

City Hospital,

Edinburgh EH10 5SB

1 Rall TW. The xanthines. In: Gilman AG, Goodman LS, Rall TW, Murad F, eds. The pharmacological basis of therapeutics. 6th ed. New York: MacMillan, 1980:592-607.

Jenne JW, Wyze E, Rood FS, MacDonald FM. Pharmacokinetics of theophylline: application to adjustment of the clinical dose of aminophylline. Clin Pharmacol Ther 1972;13:349.

3 Bukowsky M, Nakatsu K, Munt PW. Diagnosis and treatment: theophylline reassessed. Ann Intern Med 1984;101:63-73.

4 Fredholm BB. Theophylline actions on adenosine receptors. Eur $f$ Respir Dis 1980;109 (suppl):29-36.

5 Horrobin DF, Manku MS, Franks DJ, Hamet P. Methylxanthine phosphodiesterase inhibitors behave as prostaglandin antagonists in a perfused rat mesenteric artery preparation. Prostaglandins 1977;13:33-40.

6 Svedmyr K, Svedmyr N. Does theophylline potentiate inhaled beta-2 agonists? Allengy 1982;37:101-10.

7 Taylor DR, Buick B, Kinney C, Lowry RD, McDevitt DG. The efficacy of orally administered theophylline, inhaled salbutamol and a combination of the two as chronic therapy in the management of chronic bronchitis with reversible air flow obstruction. Am Rev Respir Dis 1985;131:747-51.

8 Brown IG, Chan CS, Kelly CA, Dent AG, Zimmerman PV. Assessment of the clinical usefulness of nebulised ipratropium in patients with chronic airflow limitation. Thorax 1984;39:272-6.

9 Cartwright AC. Controlled release-a regulatory dilemma. Manufacturing Chemist 1987; March:33. 0 Kelly HW. Theophylline toxicity. In: Jenne JW, Murphy S, eds. Drug therapy for asthma. Vol 31 Lung Biology in Health and Disease. New York: Marcel-Dekker, 1987:925-51.

11 Toogood JH, Baskerville J, Jennings B, Lefcoe NM, Johansson SA. Use of spacers to facilitate inhaled cortico-steroid treatment of asthma. Am Rev Respir Dis 1984;129:723-9.

12 Flenley DC, Whyte KF. Topics in chronic bronchitis and emphysema. In: Flenley DC, Petty TL, eds. Recent Advances in Respiratory Medicine IV. Churchill Livingstone, Edinburgh, 1986:193216.

13 Smith MJ, Hodson ME. High dose beclomethasone in the treatment of asthma. Lance 1983;i:265-7.

14 Postma DS, Steenhuis EJ, Van der Weele LT, Sluiter JH. Severe chronic airflow obstruction: can corticosteroids slow down progression? Eur $\mathcal{F}$ Respir Dis 1985;67:56-64.

15 Aubier M, De Troyer A, Sampson M, Macklem PT, Roussos C. Aminophylline improves diaphragmatic contractility. $N$ Engl $\mathcal{F}$ Med 1981;305:249-52.

16 Sigrist S, Thomas D, Howell S, Roussos CH. The effect of aminophylline on the respiratory muscle contractility. Am Rev Respir Dis 1982;126:46-50.

17 Moxham J, Miller J, Wiles CM, Morris AJR, Green M. Effect of aminophylline on the human diaphragm. Thorax 1985;40:288-92.

18 Murciano D, Aubier M, Lecocguic Y, Pariente R. Effects of theophylline on diaphragmatic strength and fatigue in patients with chronic obstructive pulmonary disease. $N$ Engl f Med 1984;311:349-53

19 Copper CB, Davidson AC, Cameron IR. Aminophylline, respiratory muscle strength and exercise tolerance in chronic obstructive airways disease. Bull Eur Physiopathol Respir 1987;23:15-22.

20 Eaton ML, Green BA, Church TR, MacGowan T, Niewoehner DE. Effect of theophylline in irreversible airflow obstruction. Ann Intem Med 1980;92:758-61.

21 Dull WL, Alexander MR, Sadoul P, Woolson RF. The effect of efficacy of isoproterenol for predicting the response to orally administered theophylline in chronic obstructive pulmonary predicting the response to orally administered
disease. Am Rev Respir Dis 1982;126:656-9.

22 Jenne W, Siever JR, Druz WS, Soland JV, Cohen SM, Sharp JT. The effect of maintenance theophylline therapy on lung work in severe chronic obstructive pulmonary disease while standing and walking. Am Rev Respir Dis 1984;130:600-5.

23 Evans WV. Plasma theophylline concentrations, six minute walking distances, and breathlessness in patients with chronic airflow obstruction. BrMed f 1984;289:1649-51.

24 Mahler DA, Matthay RA, Synder PE, Wells CK, Loke J. Sustained release theophylline reduces dyspnoea in non-reversible obstructive airways disease. Am Rev Respir Dis 1985;131:22-5.

25 Sharp JT. Theophylline in chronic obstructive pulmonary disease. $\mathcal{f}$ Allergy Clin Immunol 1986:78:800-5.

26 O'Neill SJ, Sitar DS, Klass DJ, Taraska VA, Kepron W, Mitenko PA. The pulmonary disposition of theophylline and its influence on human alveolar macrophage bactericidal function. Am Reo Respir Dis 1986;134:1225-8.

27 Warren PMA, Millar JS, Flenley DC, Avery A. Respiratory failure revisited: acute exacerbations of chronic bronchitis between 1961-68 and 1970-76. Lancet 1980;ii:467-71.

\section{Acetazolamide in acute mountain sickness}

During a 1969 Korean expedition to climb Lhotse in the Himalaya most of the climbers were comfortable at $4000 \mathrm{~m}$. Some had mild headache and anorexia, but one man became unconscious and remained so for three weeks. He was my introduction to acute mountain sickness. This story illustrates both the range of severity of acute mountain sickness and its idiosyncratic nature.

About half of those passing through $4243 \mathrm{~m}$ on the Everest route experience symptoms of acute mountain sickness: headache, anorexia, nausea, vomiting, insomnia, dizziness, breathlessness, and weakness. ' Some $4 \%$ suffer life threatening disease. As over 5000 visits are made each year to the high Nepal Himalaya ${ }^{2}$ this is an important problem.

The severe forms of acute mountain sickness affect the lungs, the brain, or both. We do not know whether the mechanisms of the mild and severe forms differ in nature or merely in degree. ${ }^{3}$ Does the headache of acute mountain sickness, for example, represent an early stage of cerebral oedema? Much uncertainty surrounds these mechanisms, though the main underlying cause is hypoxia rather than hypobaria. ${ }^{4}$ Oedema certainly plays a part: in the lungs it has the characteristics of a permeability oedema $\mathrm{a}^{5}$ and venous pressure is not raised; but in the brain there is no consensus on whether the oedema is vasogenic or cytotoxic. ${ }^{4}$ Impairment of the membrane pump has been postulated, ${ }^{2}$ and vascular changes have been invoked to explain pulmonary ${ }^{6}$ and cerebral $^{7}$ disease. Vascular thrombosis occurs at high 